\title{
Viðhorf Íslendinga til ætlaðs sampykkis við líffæragjafir
}

\author{
Karen Rúnarsdóttir meistaranemi ${ }^{1}$, Kjartan Ólafsson lektor ${ }^{2}$, Ársæll Arnarsson lífeðlisfræðingur ${ }^{2}$
}

\section{ÁGRIP}

Inngangur: Líffæraígræðsla er oft eina úrræðið fyrir sjúklinga sem eru með líffærabilun á lokastigi. Hér á landi er gengið út frá ætlaðri neitun, en fyrir ríkisstjórninni liggur lagabreyting um að gert verði rád fyrir ætluðu sampykki. Tilgangur pessarar rannsóknar var að kanna viðhorf íslensku pjóðarinnar til ætlaðs sampykkis við líffæragjafir. Auk pess var skoðað hversu stór hluti Íslendinga var skráður líffæragjafi, hversu mikill áhugi var á pví að gerast slíkur og hversu stór hluti vildi gefa líffæri eftir andlát. Efniviður og aðferðir: Um er að ræða pversniðsrannsókn með spurningalista. Pýðið var Íslendingar 18 ára og eldri af öllu landinu og var notast viơ póstlista frá Capacent Gallup. Í úrtakinu lentu 1400 manns og var svarhlutfall $63 \%$ (880 svör).

Niðurstöður: Meirihluti Íslendinga var hlynntur pví að gert verði ráð fyrir ætluðu sampykki (rúmlega 80\%). Konur voru líklegri til að vera hlynntar pessu en karlar, $85 \%$ á móti $76 \%$. Karlar voru helmingi líklegri til að vera hlutlausir eða andvígir. Peir sem voru yngri voru líklegri til að vera hlynntir frumvarpinu en ekki reyndist vera marktækur munur á viðhorfi eftir tekjum, búsetu eða menntun. Helmingi fleiri peirra sem áttu einhvern náinn sér sem pegið hafði líffæri voru að öllu leyti hlynntir lagasetningu. Skráđir líffæragjafar voru 5\% pátttakenda, 29 konur og 15 karlar. Ályktun: Íslendingar eru hlynntir löggjöf sem gerir ráđ fyrir ætluðu sampykki en nokkur munur er á viðhorfi eftir kyni, aldri og hvort svarendur pekkja einhvern sem hefur pegið líffæri. Meirihluti vill gefa líffæri en pó er aðeins mjög lítill hluti skráður sem líffæragjafi.
${ }^{1}$ Heilbrigðisvísindasvið̌i, 2hug- og félagsvísindasvið̌i Háskólans á Akureyri.

Fyrirspurni : Ársæll Arnarsson aarnarsson@unak.is

Greinin barst 13. maí 2014 , sampykkt til birtingar 8. september 2014

\section{Inngangur}

Líffæraígræðsla er oft eina úrræðið fyrir sjúklinga með líffærabilun á lokastigi en framfarir á pessu sviði hafa verið gríðarlegar frá pví að fyrsta velheppnaða aðgerðin var gerð í Boston árið 1954. Helsta vandamálið við pessar lækningar hefur hins vegar verið viðvarandi skortur á líffærum til ígræðslu - eftirspurn eftir peim hefur aukist hratt án pess að framboðið hafi aukist til samræmis. ${ }^{1}$ Með hækkandi meðalaldri íslensku pjóðarinnar ${ }^{2}$ og aukinni tíðni kvilla eins og sykursýki og hjartasjúkdóma má búast við að pörfin eigi eftir að aukast enn frekar.

Á árunum 1972 til 1991 voru Íslendingar einungis piggjendur af Norrænu ígræðslustofnuninni (Scandiatransplant) án pess að gefa líffæri sjálfir í staðinn. ${ }^{3}$ Árið 1991 voru hins vegar sett lög á Alpingi um brottnám líffæra ${ }^{4}$ og ákvörðun dauða ${ }^{5}$ og par með gátu Íslendingar einnig gefið líffæri til ígræðslu.

Gróflega má skipta lögum sem ríki setja sér í pessum málaflokki í tvennt. Í lögum sem gera ráð fyrir ætlaðri neitun (informed consent) er gert ráð fyrir pví að einstaklingurinn sé ekki líffæragjafi nema hann hafi útfyllt par til gerða viljayfirlýsingu um að gefa líffæri sín eftir andlát (opt-in). Vandamálið er að pegar treyst er á pess háttar pvingunarlausa fórnfýsi geta framtaksleysi og seinlæti valdið pví að fjöldi gjafa verður miklum mun minni en vilji fólks stendur til í raun. Раð veldur pví einnig að ákvörðunin lendir oftast á aðstandendum sem vita kannski ekki vilja ástvinar síns eða eru skiljanlega undir miklu álagi á peirri stundu pegar ákvörðunin parf að vera tekin. Í löndum par sem löggjöfin gerir ráð fyrir ætluðu sampykki (presumed consent) er reynt að yfirstíga slíkar hindranir með pví að ganga út frá pví að einstaklingur vilji gefa líffæri við andlát nema hann hafi sérstaklega tekið annað fram (opt-out) . $^{6}$

Hér á landi hefur ætluð neitun verið bundin í lög ${ }^{4}$ en lagt hefur verið fram nýtt frumvarp fyrir ríkisstjórn um að peim verði breytt pannig að gert verði ráð fyrir ætluðu sampykki.7 Íslendingum sem hafa áhuga á að gerast líffæragjafar eftir andlát hefur hingað til staðið til boða að fylla út svokölluð líffærakort sem eru gefin út af Embætti landlæknis og er ætlað að auðvelda ástvinum ákvarðanatöku, en pessi kort hafa ekkert lagalegt gildi og tiltölulega fáir einstaklingar virðast vita af peim og/eða hafa haft fyrir pví að fylla pau út. Pá er ekki haldið utan um pessi kort með skipulögðum hætti af opinberum aðilum og fræðsla um pau hefur verið takmörkuð. Fræðimenn hafa hins vegar ítrekað nauðsyn pess að hefðbundnari leiðir til fjölgunar líffæragjafa, eins og auglýsingar og notkun líffærakorta, verði að vera vel útfærðar og samhæfðar eigi pær að skila árangri. ${ }^{8}$ Fyrirhuguð lagabreyting par sem gert er ráo fyrir ætluðu sampykki mun hins vegar fela í sér að óparfi verður fyrir viljuga líffæragjafa að skrá sig, heldur munu peir sem eru ófúsir purfa að afskrá sig.

Ef marka má samanburð á íslenskum tölum um lifandi gjafa annars vegar og látna hins vegar kemur fram áhugavert misræmi. Íslendingar virðast pannig 
mjög viljugir pegar kemur að lifandi gjöf á líffærum og voru samkvæmt tölum Scandiatransplant ${ }^{9}$ með hæst hlutfall lifandi líffæragjafa árið 2013. Íslendingar voru hins vegar með næstlægsta hlutfall líffæragjafa eftir andlát af öllum Norðurlandapjóðunum. Pannig mætti leiða líkur að pví að Íslendingar séu í raun afar bóngóðir pegar kemur að líffæragjöf en að eitthvað í útfærslu á gjöf eftir andlát hamli pví að pessi vilji fólks nái fram að ganga.

Fræðimenn eru reyndar ekki allir sammála um hvor löggjöfin leiði af sér fleiri líffæragjafa. Samantekt Michielsen ${ }^{10}$ sýndi til að mynda að í löndum par sem lög gera ráð fyrir ætluðu sampykki eru líffæragjafar hlutfallslega fleiri en í löndum sem ekki búa við slíka löggjöf. Rannsókn Healy ${ }^{11}$ benti hins vegar til pess að munurinn stafaði ekki eingöngu af ólíkri löggjöf heldur hafi aðrir pættir áhrif á fjölda gjafa, eins og til dæmis kynningarátök sem gjarnan eru sett af stað í tengslum við breytingar á lögunum. Í nýrri hollenskri rannsókn kom aftur á móti fram að löggjöf um ætlað sampykki myndi fjölga líffæragjöfum par í landi til muna ${ }^{6}$ og ný fjölpjóðleg samanburðarrannsókn sýndi að hlutfall látinna nýrnagjafa var hærra hjá pjóðum par sem slík löggjöf var í gildi. ${ }^{12}$ En pað er ljóst að niðurstaðan af lagabreytingunum er ekki gefin, eins og sást í Chile par sem líffæragjöfum fækkaði eftir að lög voru sett sem gerðu ráð fyrir ætluðu sampykki árið 2010. ${ }^{13}$

Tilgangur rannsóknarinnar var að kanna viðhorf íslensku pjóðarinnar til pess að gengið verði út frá ætluðu sampykki við líffæragjafir og hvort einhverjir hópar hennar séu hlynntari en aðrir með tilliti til bakgrunns. Einnig var skoðað hversu stór hluti Íslendinga voru skráðir líffæragjafar, hversu mikinn áhuga fólk hafði á slíku og hversu stór hluti vill gefa líffæri eftir andlát. Auk pess var spurt hvort Íslendingar teldu líklegt að nánustu aðstandendur peirra sampykki að gefa úr peim líffæri með tilliti til pess hvort peir væru skráðir líffæragjafar eða ekki.

\section{Efniviður og aðferðir}

Um var að ræða pversniðsrannsókn par sem pýðið var Íslendingar 18 ára og eldri af öllu landinu. Úrtakið var fengið af póstlista Capacent Gallup. Hópurinn sem fyrirtækið notar fyrir viðhorfskannanir sínar samanstendur af rúmlega 24 púsund einstaklingum sem valdir hafa verið með tilviljunaraðferð úr Pjóðskrá. Capacent Gallup notast við ýmsar viðurkenndar aðferðir til að tryggja gæði úrtaksins og að hópurinn endurspegli íslensku pjóðina. Í úrtaki pessarar rannsóknar lentu 1400 manns og var svarhlutfall 63\% (880 svör).

Pátttakendur fengu sendan tölvupóst með hlekk á spurningalistann í svokölluðum Gallupvagni í febrúar 2014 og höfðu eina viku til að svara honum. Listinn var hannaður sérstaklega af rannsakendum og innihélt 5 bakgrunnsspurningar um kyn, aldur, menntun, búsetu og tekjur og 6 spurningar um viðhorf til löggjafar, viðhorf til pess að gefa eigin líffæri við andlát og hvort pátttakendur pekktu einhvern líffærapega.

Forprófun á spurningalistanum var gerð með hentugleikaúrtaki á 20 pátttakendum. Pessir forprófendur voru fyrst látnir svara spurningalistanum um líffæragjafir og að pví loknu fengu peir annan spurningalista par sem peir voru beðnir um að mynda sér skoðun á skiljanleika, lengd og orðalagi spurningalistans um líffæragjafir. Niðurstöður forprófunar voru ekki notaðar í úrvinnslu

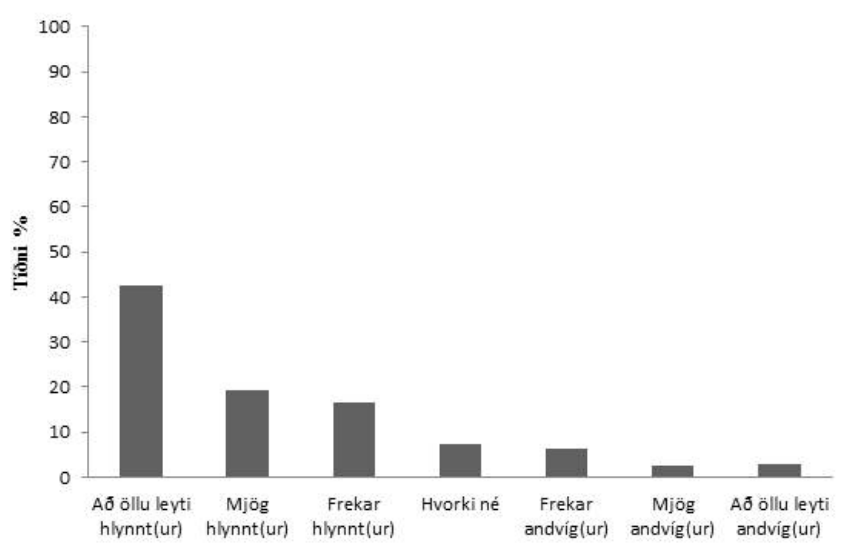

Mynd 1. Viðhorfpátttakenda til löggjafar um ætlað sampykki við liffæragjafir.

gagna enda var peim einvörðungu ætlað að auka réttmæti spurninganna.

Ekki var pörf á að sækja sérstaklega um leyfi Vísindasiðanefndar eða Persónuverndar fyrir pessa rannsókn par sem ekki var um persónurekjanleg gögn að ræða. Capacent Gallup starfar í samræmi við gildandi lög um persónuvernd og vinnur eftir ströngum siðareglum sem settar eru af ESOMAR sem eru alpjóðasamtök markaðsrannsóknafyrirtækja.

Við úrvinnslu gagna var notuð lýsandi og ályktandi tölfræði og var hún gerð í SPSS 12.0 (Statistical Package for the Social Sciences). Til pess að skoða tengsl milli breytanna voru gerð kí-kvaðrat próf og miðað við 95\% öryggismörk.

\section{Niðurstöður}

Af bakgrunnsbreytunum svöruðu allir pátttakendur spurningunum um kyn, aldur og búsetu, um 95\% svöruðu spurningunni um menntun en einungis $79 \%$ svöruðu spurningunni um fjölskyldutekjur. Kynjahlutfall var tiltölulega jafnt, $441 \mathrm{karl}$ og 439 konur. Af pátttakendum voru 23\% á aldrinum 18-34 ára, 36\% voru 35-54 og 41\% eldri en 54 ára. Búsetu var skipt í prjú svæði: Reykjavík (38\%), nágrannasveitafélög Reykjavíkur (27\%) og önnur sveitarfélög (35\%). Fjölskyldutekjum var skipt í 5 flokka en $21 \%$ pátttakendanna tóku ekki afstöðu eða voru ekki vissir um tekjur sínar. Alls reyndust $27 \%$ pátttakenda með hærri tekjur en 800 púsund, 18\% voru með tekjur á bilinu 550 til 799 púsund, 15\% á bilinu 400 til 549 púsund og 19\% voru með tekjur 399 púsund eða lægri. Um $5 \%$ pátttakenda voru óvissir eða svöruðu ekki hvaða menntun peir höfðu, 43\% voru með háskólapróf, 29\% með grunnskólapróf og 23\% með framhaldsskólapróf.

Af peim $98 \%$ pátttakenda sem svöruðu spurningunni „Pekkir pú eða veistu um einhvern sem hefur fengið líffæri eða er á biðlista eftir líffæraígræðslu?" sögðust 7\% svarenda pekkja einhvern náinn sér, $24 \%$ pekktu einhvern ekki náinn, tveir priðju pátttakenda kváðust engan pekkja og prír pátttakendur höfðu sjálfir fengið ígræðslu eða voru á biðlista eftir líffæri.

Tæplega 98\% svöruðu spurningunni „Ertu hlynnt(ur) eða andvíg(ur) pví að sett verði lög um að allir Íslendingar verði sjálfkrafa skráðir líffæragjafar en hafi kost á að afskrá sig kjósi peir pað?" (mynd 1). Eins og sjá má voru 80\% Íslendinga hlynntir hugmyndinni um ætlað sampykki en $12 \%$ andvígir. 
Tafla I. Viðhorf pátttakenda til ætlaðs sampykkis eftir aldurshópum, fjöldi (\%).

\begin{tabular}{lcccccc} 
& $18-24$ & $25-34$ & $35-44$ & $45-54$ & $55-64$ & 65 og eldri \\
\hline $\begin{array}{l}\text { Að öllu leyti } \\
\text { hlynnt(ur) }\end{array}$ & 56,3 & 54,0 & 44,5 & 42,6 & 37,8 & 30,8 \\
\hline Mjög hlynnt(ur) & 10,7 & 17,3 & 18,5 & 21,9 & 24,4 & 23,3 \\
\hline Frekar hlynnt(ur) & 11,6 & 6,0 & 16,4 & 16,8 & 23,7 & 25,8 \\
\hline Hvorki né & 9,8 & 6,0 & 6,8 & 7,1 & 7,4 & 8,8 \\
\hline $\begin{array}{l}\text { Frekar } \\
\text { andvíg(ur) }\end{array}$ & 10,7 & 6,0 & 6,8 & 6,5 & 3,7 & 4,4 \\
\hline Mjög andvíg(ur) & 0,9 & 4,7 & 3,4 & 1,3 & 2,2 & 3,1 \\
\hline $\begin{array}{l}\text { Að öllu leyti } \\
\text { andvíg(ur) }\end{array}$ & 0,0 & 6,0 & 3,4 & 3,9 & 0,7 & 3,8 \\
\hline
\end{tabular}

Pegar kynjamunur á viðhorfi til löggjafar sem gerir ráð fyrir ætluðu sampykki var skoðaður kom í ljós að konur voru marktækt hlynntari en karlar; $85 \%$ á móti $76 \%(\mathrm{p}<0,05)$. Munur eftir aldri var skoðaður (tafla I) og sást að flestir pátttakendurnir í öllum hópum eru jákvæðir. Yngri svarendur voru pó talsvert afdráttarlausari í sinni jákvæðni en peir eldri. Pessi munur milli aldurshópa og viðhorfs til löggjafar um ætlað sampykki reyndist tölfræðilega marktækur $(p<0,05)$. Enginn munur reyndist á viðhorfum eftir búsetu pátttakenda, menntun eða fjölskyldutekjum.

Af peim pátttakendum sem áttu einhvern nákominn sér sem hafði fengið líffæri eða var á biðlista eftir líffæri, sögðust 63\% vera að öllu leyti hlynntir lagasetningu par sem gengið er út frá ætluðu sampykki, en sömu skoðunar reyndust $42 \%$ peirra sem pekktu einhvern sem ekki taldist náinn og $43 \%$ peirra sem pekktu engan sem pannig var ástatt fyrir.

Enginn sem pekkti einhvern náinn sér sem purfti á líffærum að halda lýsti sig að öllu leyti andvígan lagasetningu en $2 \%$ af peim sem pekktu engan voru að öllu leyti andvígir lagasetningu sem gerir ráð fyrir ætluðu sampykki. Pessi munur milli hópanna var tölfræðilega marktækur ( $\mathrm{p}<0,05)$.

Mynd 2 sýnir hvernig svör 91\% pátttakenda sem tóku afstöðu til spurningarinnar „Hversu líklegt eða ólíklegt er að pú veitir leyfi til pess að pín eigin líffæri verði gefin við andlát?" skiptist eftir svarmöguleikum. Af peim sem svöruðu lýstu aðeins 7\% pátttakenda sig andvíga, en $84 \%$ voru jákvæðir og par af voru $39 \%$ sem sögðust alveg örugg með pá skoðun. Heilt yfir voru bæði karlar og konur jákvæð gagnvart pví að gefa eigin líffæri eftir andlát en engu að síður voru konur marktækt jákvæðari ( $\mathrm{p}<0,05)$.

Yngri pátttakendur reyndust viljugri til að gefa eigin líffæri eftir andlát en peir eldri (tafla II). Rúmlega helmingur pátttakenda

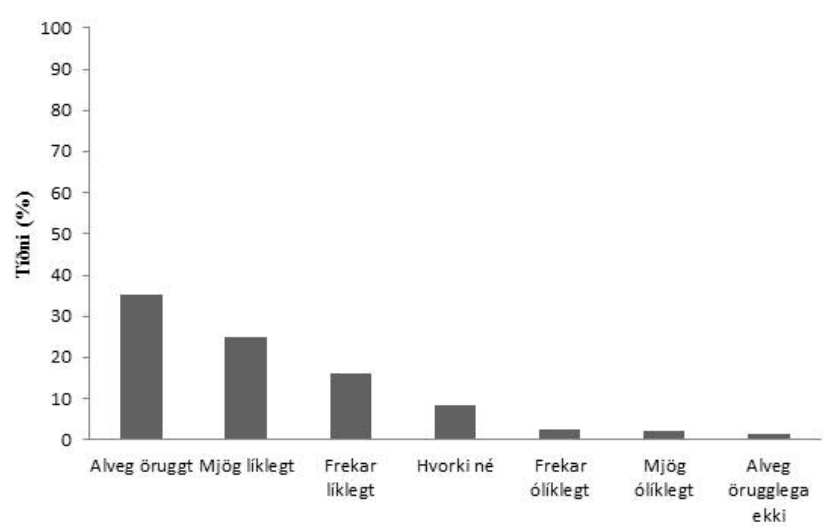

Mynd 2. Viðhorf pátttakenda til pess að gefa eigin liffæri eftir andlát.
Tafla II. Við̌horf pátttakenda til að gefa eigin liffæri eftir andlát, skipt eftir aldurshópum, fjöldi (\%).

\begin{tabular}{lcccccc}
\hline & $18-24$ & $25-34$ & $35-44$ & $45-54$ & $55-64$ & 65 og eldri \\
\hline Alveg öruggt & 51,3 & 43,7 & 46,6 & 36,5 & 36,1 & 20,7 \\
\hline Mjög líklegt & 24,3 & 27,8 & 27,1 & 33,1 & 27,8 & 24,8 \\
\hline Frekar líklegt & 12,2 & 15,9 & 18,0 & 18,2 & 18,0 & 22,1 \\
\hline Hvorki né & 8,7 & 9,5 & 6,0 & 3,4 & 12,8 & 15,2 \\
\hline Frekar ólíklegt & 3,5 & 0,8 & & 4,1 & 0,8 & 7,6 \\
\hline Mjög ólíklegt & 0,0 & 0,8 & 0,8 & 2,7 & 3,8 & 6,9 \\
\hline $\begin{array}{l}\text { Alveg } \\
\text { örugglega ekki }\end{array}$ & 0,0 & 1,6 & 1,5 & 2,0 & 0,8 & 2,8 \\
\hline
\end{tabular}

á aldrinum 18-24 ára töldu alveg öruggt að peir myndu gefa líffæri samanborið við fimmtung 65 ára og eldri. Mjög fáir ungir bátttakendur voru mótfallnir pví að gefa eigin líffæri. Pessi munur milli aldurshópa var tölfræðilega marktækur $(\mathrm{p}<0,05)$. Engin skýr tengsl fundust hins vegar milli menntunar, fjölskyldutekna eða búsetu og afstöðu til pess að gefa eigin líffæri.

Aðeins 44 pátttakendur reyndust skráðir líffæragjafar, eða 5\%. Áhugi fyrir pví að gerast skráður líffæragjafi var hins vegar mikill, $48 \%$ kváðust hafa mikinn áhuga og 26\% nokkurn. Konur reyndust marktækt jákvæðari en karlar fyrir slíkri skráningu $(\mathrm{p}<0,05)$. Yngri pátttakendur reyndust frekar hafa skráð sig sem líffæragjafa en peir sem eru eldri; 9\% í aldurshópnum 18-34 ára samanborið við 3\% 55 ára og eldri. Peir sem eru yngri höfðu einnig meiri áhuga á að skrá sig; 65\% á aldrinum 18-34 ára lýsti til að mynda yfir miklum áhuga, samanborið við 54\% á aldrinum 35-54 ára og einungis 42\% pátttakenda sem voru 55 ára og eldri. Pessir munur á aldri á viðhorfi til pess að gerast líffæragjafi reyndist tölfræðilega marktækur $(p<0,05)$. Engin skýr tengsl voru sjáanleg milli fjölskyldutekna, búsetu eða menntunar og áhuga fólks á pví að gerast líffæragjafar. Af peim sem voru skráðir líffæragjafar voru 94\% hlynntir löggjöf, samanborið við 29\% peirra sem kváðust engan áhuga hafa á að skrá sig sem líffæragjafa. Af peim sem sögðust hafa mikinn áhuga á að skrá sig sem líffæragjafa töldu 98\% mjög líklegt að peir myndu veita leyfi til að eigin líffæri væru gefin eftir andlát, en sama sögðu 16\% peirra sem engan áhuga höfðu á að skrá sig.

Pátttakendur voru beðnir um að setja sig í spor eigin aðstandenda í tveimur spurningum. Allir nema peir sem voru skráðir líffæragjafar voru beðnir um að taka afstöðu annars vegar til spurningarinnar „Ef pú værir skráður líffæragjafi, hversu líklegt eða ólíklegt telur pú að fjölskylda pín myndi sampykkja að gefa úr pér líffæri við andlát?“ og hins vegar til „Ef pú værir ekki skráður líffæragjafi, hversu líklegt eða ólíklegt telur pú að fjölskylda pín myndi sampykkja að gefa úr pér líffæri við andlát?"

Eins og sést í töflu III töldu flestir svarendur mun líklegra að aðstandendur myndu gefa úr peim líffærin ef peir væru skráðir líffæragjafar en mun færri töldu pað líklegt ef peir væru ekki skráðir gjafar og par af voru $11 \%$ sem töldu pað alveg öruggt. Alls voru 14 einstaklingar á pví að fjölskylda sín myndi neita beiðni um líffæragjöf ef peir væru ekki skráðir.

\section{Umræða}

Niðurstöður sýndu að Íslendingar eru afar jákvæðir í garð löggjafar par sem gert er ráð fyrir ætluðu sampykki við líffæragjafir. Stuðn- 
Tafla III. Líkur sem taldar eru á að fjölskylda gefi liffæri eftir pví hvort viðkomandi væri skráđur liffæragjafi eða ekki, fjöldi (\%).

\begin{tabular}{lcc} 
& Ef skráđur & Ef ekki skráour \\
Alveg öruggt & 26,8 & 10,6 \\
\hline Mjög líklegt & 33,2 & 29,5 \\
\hline Frekar líklegt & 20,2 & 27,1 \\
\hline Hvorki né & 3,0 & 10,4 \\
\hline Frekar ólíklegt & 1,9 & 5,1 \\
\hline Mjög ólíklegt & 1,0 & 3,6 \\
\hline Alveg örugglega ekki & 0,1 & 1,6 \\
\hline Veit ekki & 8,7 & 12,2 \\
\hline Svarar ekki & 5,0 & 0,0 \\
\hline
\end{tabular}

ingur við slíka löggjöf er tvöfalt meiri hérlendis en mælst hefur í öðrum löndum. ${ }^{14,15}$ Alls $80 \%$ pátttakenda sögðust vera hlynntir henni en $12 \%$ voru á móti. Fram kom að konur voru jákvæðari en karlar og einnig peir sem pekktu einhvern sem hafði fengið líffæri eða var á biðlista eftir líffæraígræðslu. Peir yngri voru einnig frekar jákvæðari í viðhorfum sínum gagnvart líffæragjöf en peir eldri. Möguleg skýring á pessum mun á milli aldurshópa gæti verið sú að peir eldri kunni að hafa efasemdir um að líffæri peirra henti lengur til líffæragjafar sökum aldurs eða sjúkdóma. Slíkar skýringar hafa komið fram í öðrum rannsóknum. ${ }^{16,17}$

Prátt fyrir afar jákvætt viðhorf reyndust einungis 5\% pátttakenda vera skráðir líffæragjafar. Petta hlutfall er mjög lágt miðað við aðrar pjóðir og má nefna að í stórri rannsókn sem tók til ungs fólks bæði í Bandaríkjunum og Evrópu kom í ljós að rúmlega priðjungur kvaðst vera skráður líffæragjafi. ${ }^{18}$ Pessi munur á ætlan og efndum Íslendinga sést einnig gjörla á pví að 84\% svarenda segjast tilbúnir að gefa sín líffæri eftir andlát, sem er talsvert hærra hlutfall en í öðrum löndum, pað sama á til að mynda við um $64 \%$ Breta $^{19}$ og um $62 \%$ Svía. ${ }^{16}$

Pátttakendur töldu mun líklegra að fjölskyldur peirra veittu leyfi ef peir væru skráðir líffæragjafar. Pó töldu 3\% ólíklegt að fjölskylda peirra myndi sampykkja að gefa úr peim líffæri prátt fyrir skýran vilja viðkomandi. Petta er í samræmi við rannsókn Domínguez-Gil og félaga ${ }^{20}$ par sem skoðað var viðhorf til líffæragjafa á Spáni. Í henni kom fram að árið 1993 neituðu aðstandendur í 3\% tilvika pó svo að skýr vilji hins látna til líffæragjafar væri til staðar. Tíðni slíkra neitana jókst með árunum og árið 1999 kom hún fram í 4\% tilvika en 6\% árið 2006. Rannsóknin sýndi einnig að ef ekki var til staðar skýr ósk um líffæragjöf, var enn líklegra að aðstandendur neituðu að gefa líffæri. Í samskonar rannsókn frá Bretlandi kom fram að 6\% aðstandenda neituðu að gefa líffæri prátt fyrir að skýr vilji fyrir líffæragjöf hjá peim látna hafi verið til staðar. ${ }^{21}$ Aukin tíðni neitunar kom einnig fram í íslenskri langtímarannsókn Sigurbergs Kárasonar og félaga, ${ }^{22}$ en $40 \%$ aðstandenda neituðu líffæragjöf pegar eftir henni var leitað.

Pessi rannsókn dregur fram ákveðið misræmi milli mjög jákvæðrar afstöðu fólks til pess að gefa eigin líffæri og pess hversu fáir hafa skráð sig sem líffæragjafar. Ekki er gott að segja til um hvað veldur, en kannski er framkvæmd slíkra skráninga hér á landi ekki með peim hætti að fólki sé gert petta nægilega auðvelt. Einnig eru pátttakendur ekki allir sannfærðir um að aðstandendur peirra muni taka ákvörðun í samræmi við pennan jákvæða vilja enda sýna innlendar og erlendar rannsóknir að viðhorf fjölskyldna er ekki eins jákvætt. Líklega skýrist pað af pví að eflaust hafa fæstir fjölskyldumeðlimir fengið skýr skilaboð um vilja einstaklinga til gjafa.

Löggjöf sem gerir ráð fyrir ætluðu sampykki getur ekki leyst allan vanda við líffæragjafir og henni fylgja einnig ýmsar siðferðisspurningar. Fjölskylda hins látna mun eftir sem áður geta komið í veg fyrir að af líffæragjöf geti orðið. Аð auki má spyrja sig að pví hvort heilbrigðisyfirvöld séu að nýta sér framtaks- eða athugunarleysi borgarana með pví að ætla peim sjálfkrafa sampykki. Sumir fræðimenn ${ }^{23}$ hafa lagt til að petta vandamál sé best leyst með pví hreinlega að skylda fólk til að taka afstöðu til gjafar á eigin líffærum eftir andlát (mandated choice). En jafnvel pó að slíkt myndi draga úr siðfræðilegum agnúum ætlaðs sampykkis, er óljóst hvaða áhrif pað hefði á fjölda gjafa. Ennfremur geta jafnvel haganlegustu yfirlýsingar ekki tekið tillit til allra aðstæðna né eytt öllum efasemdum. ${ }^{8}$ Væri slík leið hins vegar farin, mætti sjá fyrir sér að fólk pyrfti til dæmis að taka afstöðu til ráðstöfunar eigin líffæra við endurnýjun ökuskírteinis.

Eins og í öllum viðhorfskönnunum sem styðjast við spurningalista eru ákveðnar takmarkanir við túlkun pessara niðurstaðna. Spurningarnar voru fyrirfram ákveðnar og ósveigjanlegar og peim var einungis hægt að svara með tilteknum lokuðum svarmöguleikum. Pví er erfitt að segja til um hvort allir pátttakendur hafi skilið pað sem við var átt og hvort uppgefnir svarmöguleikar hafi að fullu endurspeglað skoðanir peirra og tilfinningar til svo flókins málefnis. Pá er einnig ljóst að með pessari aðferð litast rannsóknin mjög af hugmyndum rannsakenda um hvað sé mikilvægt og hvað ekki. Engin leið er heldur fær til pess að ákvarða hversu mikla umhugsun pátttakandi leggur í svör sín né heldur hvort hann segir alltaf rétt frá sínum skoðunum. En pessi nálgun hefur einnig sína kosti. Pannig fæst allgott svarhlutfall úr nokkuð stóru úrtaki sem valið er úr Pjóðskrá af sérfræðingum Gallup. Staðlaðar spurningar og svarmöguleikar auka við áreiðanleika og gera hlutlæga tölfræðiúrvinnslu mögulega, sem og samanburð við aðrar rannsóknir. Spurningalistinn var einnig forprófaður með tilliti til skiljanleika, lengdar og orðalags og lagaður til að mæta peim athugasemdum sem upp komu. ${ }^{23}$

Augljóst er af niðurstöðum rannsóknarinnar að Íslendingar eru mjög jákvæðir gagnvart pví að gefa eigin líffæri eftir andlát, en lítið hlutfall peirra hefur samt skráð sig sem líffæragjafa. Höfundum pykir ljóst að hægt sé að ná miklum árangri í fjölgun líffæragjafa á Íslandi, hvort sem pað væri gert með lagabreytingum eða öðrum leiðum.

\section{Pakkir}

Pakkir fá styrktaraðilar rannsóknarinnar: Actavis, Fjölval, Lyfja og Öryggismiðstöðin. 


\section{Heimildir}

1. Pálsson R. Betur má ef duga skal. Læknablaðið 2005; 91 404-5.

2. Hagstofa Íslands - Hagtíðindi 2013;2. www.hagstofa.is ágúst 2013

3. Grunnet N, Asmundsson P, Bentdal O, Madsen M, Persson $\mathrm{NH}$, Salmela $\mathrm{K}$, et al. Organ donation, allocation, and transplantation in the Nordic countries: Scandiatransplant 1999. Transplant Proc 2001; 33: 2505-10.

4. Lög um brottnám líffæra nr. 16/1991 með áorðnum breytingum 61/1998. althingi.is/lagas/140a/1991016. html - september 2014

5. Lög um ákvörðun dauða nr. 15/1991 með áorðnum breytingum 162/2010. althingi.is/lagas/143a/1991015. html - september 2014

6. van Dalen HP, Henkens K. Comparing the effects of defaults in organ donation systems. Soc Sci Med 2014; 106 137-42. DOI: 10.1016/j.socscimed.2014.01.052

7. Frumvarp til laga um breytingu á lögum um brottnám líffæra 16/1991. althingi.is/altext/143/s/0034.html september 2014

8. Garcia-Valdecasas JC. European approach to increasing organ donation: European Union donor card, presumed consent, and other innovations. Liver Transpl 2012; 18(Supp2): s8-s9. DOI: 10.1002/lt.23538

9. Scandiatransplant. Transplantation figures for 1. Quarter 2014 scandiatransplant.org/data/copy_of_sctp_figures 2014 _1Q.pdf - september 2014.
10. Michielsen P. Presumed consent to organ donation: 10 years experience in Belgium. J Roy Soc Med 1996; 89: 6636

11. Healy K. Do Presumed Consent Laws Raise Organ Procurement Rates? DePaul LawReview 2006; 55: 1017-43.

12. Bendorf A, Pussell BA, Kelly2 PJ, Kerridge IH. Socioeconomic, demographic and policy comparisons of living and deceased kidney transplantation rates across 53 countries. Nephrol 2013; 18: 633-40.

13. Dominguez J, Rojas JL. Presumed consent legislation failed to improve organ donation in Chile. Transpl Proc 2013; 45: 1316-7. DOI: 10.1016/j.transproceed.2013.01.008

14. Rithalia A, McDaid C, Suekarran S, Myers L, Sowden A. Impact of presumed consent for organ donation on donation rates: a systematic review. BMJ 2009; 338: 1-8.

15. Sanner, M. A Comparison of Public Attitudes Toward Autopsy, Organ Donation, and Anatomic Dissection: A Swedish Survey. JAMA 1994; 271: 284-8.

16. Sanner MA. People's attitudes and reactions to organ donation. Mortality 2006; 11: 133-50.

17. Boulware L, Ratner L, Sosa J, Cooper L, LaVeist T, Powe N. Determinants of willingness to donate living related and cadaveric organs: identifying opportunities for intervention. Transpl 2002; 73: 1683-91.
18. Mocana N, Tekinb E. The determinants of the willingness to donate an organ among young adults: Evidence from the United States and the European Union. Soc Sci Med 2007; 65: 2527-38.

19. Coad L, Carter N, Ling J. Attitudes of young adults from the UK towards organ donation and transplantation. Transpl Res 2013, 2: 9

20. Domínguez-Gil B, Martín MJ, Valentín MO, Scandroglio $B$, Coll E, López, JS, et al. Decrease in refusals to donate in Spain despite change in the populations attitude towards donation. Org Tiss Cells 2010; 13: 17-24.

21. British Medical Association. Building on progress: Where next for organ donation policy in the UK. bma.org.uk/ september 2014.

22. Karason S, Johannsson R, Gunnarsdottir K, Asmundsson P, Sigvaldason K. Líffæragjafir á Íslandi 1992-2002. Læknablaðið 2005; 91: 417-22.

23. Spital A. Mandated choice for organ donation: time to give it a try. Ann Int Med 1996; 125: 66-9.

24. Schutt RK. Investigating the Social World. The Process and Practice of Research (7. útg.). Sage Publication, Boston 2012.

ENGLISH SUMMARY

\section{Public Attitudes Towards Presumed Consent in Organ Donation in Iceland}

Karen Runarsdottir, Kjartan Olafsson, Arsaell Arnarsson

Introduction: Organ transplant is often the only viable treatment for patients with end-stage organ failure. Until now, Icelandic legislation has required informed consent for organ donors, but a new parliamentary bill has been put forth to change the laws to presumed consent. The goal of this study was to investigate the attitude of the Icelandic population towards legislative changes to presumed consent.

Materials and methods: Descriptive cross-sectional study using a questionnaire. The study population included all Icelanders, 18 years and older. The sample involved 1400 persons randomly selected from a Capacent Gallup mailing-list. The response rate was $63 \%$ or 880 answers.

Results: The majority of Icelanders are in favour of the proposed legislative change (more than $80 \%$ ). Women were more likely to support presumed consent than men, $85 \%$ versus $76 \%$ respectively. Younger participants were more likely to be positive towards the new law, but no significant difference was found in attitude by family income, demographics or education. Persons who knew someone close to them that had received a transplanted organ were $50 \%$ more likely to be in complete agreement with the proposed legislation. Only $5 \%$ of participants were currently registered organ donors -29 women and 15 men.

Conclusion: Icelanders are very positive towards changing the law to include presumed consent in organ donation. Women and younger people tended to be more in favour and similarly those who know someone that has received donated organs. A majority of responders are willing to donate their organs, but very few are registered as donors.

Key words: Organ donations, transplantations, presumed consent, public attitude.

Correspondence: Ársæll Arnarson, aarnarson@unak.is 